Przegląd Badań Edukacyjnych Educational Studies Review

ISSN 1895-4308

nr $21(2 / 2015)$, s. 137-152

METAANALIZY

BADAN

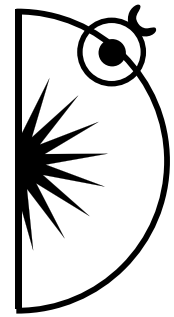

Sławomira Sadowska

Uniwersytet Gdański, e-mail: s.sadowska@ug.edu.pl

Zdzisława Janiszewska-Nieścioruk

Uniwersytet Zielonogórski, e-mail: zjn@onet.pl

\title{
0 dobrodziejstwie starej, dobrej szkoły specjalnej w perspektywie realizacji obowiązku szkolnego przez uczniów niepełnosprawnych - napięcia między ideą integracji a rzeczywistością
}

http://dx.doi.org/10.12775/PBE.2015.052

\section{The blessing of The Good Old Special School in Terms of Mandatory Education of Pupils with Disabilities - The Tension Between the Idea of Integration and Reality}

\begin{abstract}
Since the $90 \mathrm{~s}$ of the $20^{\text {th }}$ century we can observe the expansion of opening spaces in public schools for pupils with disabilities. The ongoing discourse about the non-segregation education is increasingly reinforcing the negative belief about the importance of traditional forms of education. In this context the article considers the value of special schools. The direction of the conducted analyses is focused on intensifying the reflection on what is political, what is possible, and what is everyday in the school's reality. The starting point of the analyses was the look at the typical educational paths of pupils with disabilities which clearly present the phenomenon of "expulsion" or "returns" from integration. In the next passage, in reference to the variety of research, the article shows the experience of pupils with disabilities in non-segregation forms and the importance of special schools in building/rebuilding their sense of competence, self-esteem, and good relations with teachers and peers. The experiences of public and integration schools are a testimony to the fact
\end{abstract}


that hidden patterns of the schools' culture are often in conflict with the patterns of overt culture.

Key words: special school; integration; community education; disability

\section{Wprowadzenie}

Po transformacji ustrojowej w Polsce uwaga naukowców kierowana jest przede wszystkim ku nowym - integracyjnym - rozwiązaniom szkolnym, społecznym czy zawodowym na rzecz osób z niepełnosprawnościami. Opisywany jest zatem raczej fenomen integracji, włączania i alternatyw wspólnego życia niż praktyk szkolnych w obecnych od dawna szkołach specjalnych, działań podejmowanych w miejscu szkoły specjalnej przez nauczycieli i uczniów czy wzorów orientacji i interpretacji rzeczywistości podzielanych przez uczniów i nauczycieli tych szkół. Prowadzone tu rozważania mają w naszym zamiarze dostarczyć przesłanek do wnikliwszego namysłu nad ocenami specjalnych form kształcenia osób z niepełnosprawnością (szkół specjalnych), które w relacji do makrodyskursów i procesów społecznych, wyznaczających określoną politykę i praktykę oświatową, często są negatywne. Podstawą rewidowania stanowisk na temat środowiska szkoły specjalnej uczyniłyśmy m.in. tropy z rekonstrukcji ścieżek wiodących uczniów z niepełnosprawnością przez różne miejsca, które przywiodły te osoby do szkoły specjalnej, badania znaczeń przypisywanych przez nich własnemu uczestnictwu edukacyjnemu i codzienności szkolnej. Odwołujemy się m.in. do wyników badań biograficznych osób z niepełnosprawnością, wyników badań subiektywnej jakości życia, a także wyników raportów edukacyjnych oraz innych doniesień badawczych, które były realizowane za pomocą metod ilościowych - ankietowo-kwantytatywnych. Badania ilościowe niejednokrotnie stanowią dopełnienie zaprezentowanych wyników realizowanych w strategii jakościowej. Liczymy na to, że analizy umocnią refleksję pedagogiczną w toczącym się od lat dyskursie o niesegregacyjnym kształceniu niepełnosprawnych.

\section{Tło analiz - szkoła specjalna w statystykach oświatowych i danych GUS}

Pomimo zauważalnego wyraźnego skoku w powstawaniu klas integracyjnych - zarówno w przypadku szkół podstawowych, jak i gimnazjów - liczba szkół 
specjalnych utrzymuje się na stałym poziomie od wielu lat. Dane GUS wskazuja, że większość szkół specjalnych zlokalizowana jest w mieście, a tylko około $1 / 4$ na wsi (por. tabela1).

Tabela 1. Szkoły podstawowe specjalne oraz gimnazja specjalne w podziale na miasto i wieś

\begin{tabular}{|l|c|c|c|c|c|c|}
\hline \multirow{2}{*}{ Rok szkolny } & \multicolumn{3}{|c|}{ Szkoły podstawowe specjalne } & \multicolumn{3}{c|}{ Gimnazja specjalne } \\
\cline { 2 - 7 } & Miasto & Wieś & Ogółem & Miasto & Wieś & Ogółem \\
\hline $1990 / 1991$ & 607 & 162 & 769 & & & \\
\hline $1995 / 1996$ & 620 & 156 & 776 & & & \\
\hline $2000 / 2001$ & 631 & 149 & 780 & 614 & 139 & 753 \\
\hline $2001 / 2002$ & 616 & 141 & & 611 & 144 & \\
\hline $2002 / 2003$ & 637 & 146 & & 647 & 158 & \\
\hline $2003 / 2004$ & 634 & 145 & & 651 & 162 & \\
\hline $2004 / 2005$ & 632 & 138 & & 655 & 154 & \\
\hline $2005 / 2006$ & 634 & 138 & 772 & 654 & 152 & 806 \\
\hline $2006 / 2007$ & 640 & 138 & & 665 & 155 & \\
\hline $2007 / 2008$ & 644 & 146 & 790 & 660 & 156 & 816 \\
\hline $2008 / 2009$ & 632 & 144 & 776 & 662 & 162 & 824 \\
\hline $2009 / 2010$ & 635 & 142 & 777 & 659 & 162 & 821 \\
\hline $2010 / 2011$ & 634 & 146 & 780 & 661 & 161 & 822 \\
\hline $2011 / 2012$ & 637 & 149 & 780 & 660 & 170 & 830 \\
\hline $2012 / 2013$ & 634 & 147 & 781 & 665 & 175 & 840 \\
\hline $2013 / 2014$ & 612 & 148 & 780 & 660 & 179 & 839 \\
\hline
\end{tabular}

Źródło: dane GUS.

Ponad $2 / 3$ szkół specjalnych stanowi element większego zespołu, gdy jedynie co 20 szkoła ogólnodostępna i co 5 szkoła integracyjna funkcjonuje w zespole szkół. Szkoły specjalne należą do szkół małych i często nie przekraczają liczby 100 uczniów. W roku szkolnym 2013/2014 w szkołach specjalnych na poziomie podstawowym i gimnazjalnym przebywało odpowiednio 23408 i 26 351 uczniów $^{1}$. Szczegółowe omówienie danych odnoszących się do wcześniejszych lat odnaleźć można m.in. w opracowaniu Iwony Chrzanowskiej (2009, s. 204-216; 225-232), do którego odwołujemy czytelnika.

${ }^{1}$ Strona z danymi GUS: http://www.stat.gov.pl (dostęp: 20.06.2015). 
Najliczniejszą kategorię uczniów ze specjalnymi potrzebami edukacyjnymi stanowią dzieci z niepełnosprawnością intelektualną w stopniu lekkim. Zgodnie z danymi Informacji Oświatowej (SIO) ${ }^{2}$ (stan na 30.09.2014 r.) na etapie szkoły podstawowej uczyło się 17504 uczniów z niepełnosprawnością intelektualną w stopniu lekkim, z czego $6675 \mathrm{w}$ szkołach podstawowych specjalnych, a $10829 \mathrm{w}$ innych szkołach. Na etapie gimnazjum liczba uczniów z niepełnosprawnością intelektualną w stopniu lekkim wynosiła 16 750, z czego 7696 uczyło się w gimnazjach specjalnych, a 9054 poza szkolnictwem specjalnym.

Obraz szkół specjalnych można uzupełnić o kolejne dane liczbowe, posiłkując się raportem IBE z badań prowadzonych w latach 2013-2014 w losowo wybranych z całej Polski szkołach (Grzelak, Kubicki, Orłowska, 2014). Elementem tego ostatniego badania były opinie dyrektorów dotyczące dostępności szkoły i dostosowania do potrzeb osób z niepełnosprawnością. Pod kategorią dostępności szkoły dla osób z niepełnosprawnością „rozumiano w badaniu nie tylko brak barier architektonicznych, ale też odpowiednie wyposażenie szkół w sprzęt i pomoce naukowe, dostępność odpowiednio wykwalifikowanej kadry. Krótko mówiąc, uznano, że szkoła dostępna to taka, która jest wszechstronnie przygotowana na przyjęcie osób z różnymi niepełnosprawnościami” (Grzelak, Kubicki, Orłowska, 2014, s. 124). Warto za badaczami zastrzec, że zebrane wypowiedzi są subiektywną oceną przedstawiciela władz szkolnych, a nie efektem audytu dostępności. Łącznie zrealizowano 1261 wywiadów z dyrektorami, w tym 590 w szkołach ogólnodostępnych, 409 integracyjnych oraz 262 specjalnych. Zdecydowanie dobrze o poziomie dostosowania wypowiedziało się $60 \%$ dyrektorów szkół specjalnych, a 32\% raczej dobrze, jedynie nieliczni określili ten poziom jako zdecydowanie zły. W przypadku dyrektorów ze szkół ogólnodostępnych, choć liczba ocen zdecydowanie negatywnych się nie różniła, to ponad połowa (53\%) mówiła o raczej dobrym, a jedynie co piąty (18\%) o bardzo dobrym dostosowaniu (Grzelak, Kubicki, Orłowska, 2014, s. 125). Relatywnie najwyższy poziom deklarowanej dostępności występuje w przypadku pomocy dydaktycznych, np. podręczników, map, powiększalników itp. Jako szkołę „,bez barier" (w pełni dostosowana) określa swoją szkołę trzech na pięciu (62\%) dyrektorów ze szkół specjalnych, dwóch na pięciu (38\%) ze szkół integracyjnych i prawie co trzeci dyrektor szkoły ogólnodostępnej (29\%). Na brak dostosowania w tym zakresie wskazuje $8 \%$ dyrektorów szkół ogólnodostępnych, 3\% integracyjnych i jedynie 1\% ze szkół specjalnych (Grzelak, Kubicki, Orłowska,

2 Strona z danymi SIO: http://www.cie.men.gov.pl/index.php/dane-statystyczne/139.html (dostęp: 20.06.2015). 
2014, s. 128). Relatywnie najniższy deklarowany poziom dostosowania występuje w przypadku form komunikacji - 50\% dyrektorów szkół specjalnych wskazuje na pełne dostosowanie do potrzeb, gdy taki poziom wskazuje jedynie $6 \%$ dyrektorów szkół ogólnodostępnych. Na brak dostosowania form komunikacji wskazuje jedynie 9\% dyrektorów szkół specjalnych i aż 61\% dyrektorów szkół ogólnodostępnych oraz 33\% integracyjnych (Grzelak, Kubicki, Orłowska, 2014, s. 128). Szkoły specjalne najczęściej dysponują pomieszczeniami do prowadzenia zajęć specjalistycznych z uczniem (91\%), a w dalszej kolejności integracyjne (52\%) i ogólnodostępne (22\%). W opinii dyrektorów szkół realizacja zaleceń poradni psychologiczno-pedagogicznej przebiega najbardziej bezproblemowo w szkołach specjalnych (76\%), w dalszej kolejności w szkołach ogólnodostępnych (53\%) i integracyjnych (52\%) (Grzelak, Kubicki, Orłowska, 2014, s. 138). Na braki w zatrudnieniu dodatkowych pracowników pedagogicznych lub niepedagogicznych, by móc w pełni efektywnie pracować z dziećmi z niepełnosprawnościami, w najmniejszym stopniu wskazują dyrektorzy szkół specjalnych (28\%). Takie braki występują według prawie połowy $(48 \%) \mathrm{dy}-$ rektorów szkół ogólnodostępnych i 39\% rozmówców ze szkół integracyjnych. Dyrektorzy szkół ogólnodostępnych wskazują na braki kadrowe psychologów (40\%), nauczycieli wspomagających (28\%), logopedów i pomocy nauczyciela (po 23\%), pedagogów specjalnych (14\%) i na koniec innych pracowników niewymienionych wcześniej - 13\% wskazań. Potrzeby kadrowe szkół integracyjnych i specjalnych są odpowiednio mniejsze, choć w tym przypadku na pierwszym miejscu wskazuje się konieczność zatrudnienia pomocy nauczycielaodpowiednio $22 \%$ i $21 \%$ - oraz psychologa - 26\% i 12\% ( Grzelak, Kubicki, Orłowska, 2014, s. 131).

Ten wstępny ogląd pozwala zauważyć, że zwiększenie liczby ofert edukacyjnych dla niepełnosprawnych dzieci nie idzie w parze ze stworzeniem odpowiednich warunków w szkołach, zwłaszcza ogólnodostępnych. Jest to niepokojące, gdy uwzględnimy, że oczekiwane staje się zwiększenie odsetka uczniów w ramach edukacji włączającej, co odnieść można do założeń ratyfikowanej przez Polskę 6 września 2012 r. Konwencji ONZ o prawach osób niepełnosprawnych $^{3}$, a zwłaszcza z art. 24, w którym czytamy „Państwa Strony zapewnią włączający system kształcenia [...] osoby niepełnosprawne będą korzystać z włączającego, bezpłatnego nauczania obowiązkowego wysokiej jakości, na poziomie podstawowym i średnim, na zasadzie równości z innymi osobami,

${ }^{3}$ https://www.rpo.gov.pl/pl/konwencja-o-prawach-osob-niepelnosprawnych (dostęp: 17 maja 2015). 
w społecznościach, w których żyją". Model kształcenia ukonkretnia najnowsza regulacja prawna ${ }^{4} \mathrm{w}$ sprawie warunków organizowania kształcenia, wychowania i opieki dla dzieci oraz młodzieży niepełnosprawnych, niedostosowanych społecznie i zagrożonych niedostosowaniem społecznym.

\section{Walor szkół specjalnych w kontekście analizy ścieżek edukacyjnych uczniów i rekonstrukcji doświadczeń uczniów zmieniających szkołę}

W systemie polskiej oświaty, kształcenie specjalne realizowane jest na podstawie orzeczenia o potrzebie kształcenia specjalnego wydanego przez zespół orzekający działający w publicznej poradni psychologiczno-pedagogicznej. W praktyce, w procesie decyzyjnym o kształceniu specjalnym, ważna rola przypada rodzicom. To rodzice decyduja, czy ich dziecko zostanie zbadane w poradni psychologiczno-pedagogicznej, oni podejmują decyzję, czy dostarczyć szkole orzeczenie o potrzebie kształcenia specjalnego (podejmują decyzję, czy - w myśl litery prawa oświatowego - ich dziecko można będzie uznać za niepełnosprawne), a w przypadku decyzji o przedłożeniu szkole orzeczenia wybierają też instytucję, do której dziecko będzie uczęszczać: ogólnodostępną, integracyjną lub specjalną. Zawarta w zaleceniach orzeczenia o potrzebie kształcenia specjalnego rekomendowana forma kształcenia ma charakter niewiążący i jest jedynie wskazówką dla rodzica, który podejmuje ostateczną decyzję. W praktyce rodzice w przeważającej większości $(89 \%)$ wybierają dla swoich dzieci szkoły zgodnie z rekomendacja poradni (por. Grzelak, Kubicki, Orłowska, 2014, s. 36). Orzeczenie - poza różnymi skutkami prawnymi - jest więc bardzo istotnym czynnikiem wpływającym na wybór danej formy kształcenia. Badacze wskazują, że decyzję dotyczącą formy kształcenia dziecka rodzice uzależniają od odpowiednich warunków, jakie winna spełniać szkoła (Bieniada-Krakiewicz, 1987), ponadto w podjęciu decyzji o wyborze szkoły ważny jest lęk rodziców związany z przewidywaniem niepowodzeń, które mogą spotkać ich dziecko w szkole. Największy lęk związany z uczęszczaniem dzieci do szkoły integracyjnej przejawiają rodzice dzieci z niepełnosprawnością intelektualną i wzrokową (por. Kossewska, 2000, s. 110). Barbara Grzyb, badając uwarun-

\footnotetext{
${ }^{4}$ Rozporządzenie Ministra Edukacji Narodowej z dnia 24 lipca 2015 r. w sprawie warunków organizowania kształcenia, wychowania i opieki dla dzieci i młodzieży niepełnosprawnych, niedostosowanych społecznie i zagrożonych niedostosowaniem społecznym (Dz.U. 2015 poz. 1113)
} 
kowania związane z przenoszeniem uczniów z niepełnosprawnością ze szkół integracyjnych do specjalnych, zauważa, że znaczącym czynnikiem przy wyborze szkoły integracyjnej jest wiedza rodziców o funkcjonowaniu edukacji integracyjnej, powiązana często z sugestywnością nauczycieli i rodziny. Ponadto rodzice uwzględniają również stan zdrowia dziecka, negatywne opinie o szkole specjalnej, a także odległość placówki od miejsca zamieszkania (Grzyb, 2013, s. 276).

Zgodnie z danymi Systemu Informacji Oświatowej (SIO), o ile na wczesnym etapie edukacji większość uczniów uczęszcza do przedszkoli ogólnodostępnych, o tyle z każdym kolejnym etapem edukacji wzrasta udział uczniów w szkołach i placówkach specjalnych. Oznacza to, że mamy do czynienia ze zjawiskiem zmiany szkoły w toku edukacji. Szczegółowych informacji w tym zakresie dostarcza najnowszy raport badań ścieżek edukacyjnych uczniów (Grzelak, Kubicki, Orłowska, 2014). Badani rodzice (przeprowadzono łącznie 6236 wywiadów z rodzicami uczniów z niepełnosprawnością ukierunkowanych na zebranie informacji na temat zróżnicowania ścieżek edukacyjnych i zawodowych dzieci oraz młodzieży z niepełnosprawnością, uwarunkowań decyzji edukacyjnych na progu przejścia z jednego etapu edukacyjnego do kolejnego oraz społeczno-ekonomicznego kontekstu funkcjonowania gospodarstw domowych z osobami z niepełnosprawnością) deklarowali, że nie mieli problemów z wyborem preferowanej szkoły. Jedynie 2,6\% rodziców stwierdziło, że szkoła, do której zostało przyjęte dziecko, nie była tą preferowaną. Wśród uczniów szkół podstawowych 30,5\% zmieniło szkołę pierwszego wyboru. Analiza danych w odwołaniu do systemowego podziału na szkolnictwo ogólnodostępne, integracyjne oraz specjalne wskazuje, że zmiana szkoły specjalnej występuje najrzadziej (11\%), wyższy odsetek przypada szkołom integracyjnym (16,7\%), a najwyższy $(72,3 \%)$ ogólnodostępnym - prawie 3/4 uczniów zmieniających szkołę pierwszego wyboru na etapie szkoły podstawowej to uczniowie szkoły ogólnodostępnej (Grzelak, Kubicki, Orłowska, 2014, s. 46-47). Najczęstszym przywoływanym przez rodziców powodem zmiany szkoły jest stwierdzenie, że dziecko nie radziło sobie ze względu na niepełnosprawność. Prawie połowa przypadków odejść ze szkół ogólnodostępnych i integracyjnych to przeszacowanie możliwości dziecka. Relatywnie rzadziej to uzasadnienie pojawia się w odniesieniu do szkół specjalnych. Powodem specyficznym dla szkół specjalnych jest zmiana miejsca zamieszkania (Grzelak, Kubicki, Orłowska, 2014, s. 47). Na etapie gimnazjum zaledwie $5,4 \%$ uczniów z niepełnosprawnością zmieniało szkołę pierwszego wyboru - głównie zmiany obejmowały gimnazjum ogólnodostępne $(69,1 \%)$, ale odnosiły się także do szkół integracyjnych 
$(16,2 \%)$ i specjalnych $(14,7 \%)$. Najczęściej wymienianym powodem, bez istotnego zróżnicowania statystycznego, lecz z przewagą szkół ogólnodostępnych, było nieradzenie sobie w szkole ze względu na niepełnosprawność (Grzelak, Kubicki, Orłowska, 2014, s. 65).

Na podobne przyczyny zmiany ścieżki edukacyjnej zwraca uwagę Grzyb (2013). Śledząc uwarunkowania przeniesienia uczniów z niepełnosprawnością ze szkół integracyjnych do specjalnych (w związku z wydaniem nowego orzeczenia), ustaliła, że przyczyny zmiany szkoły wynikają z trudności szkolnych i niespełnienia oczekiwań stawianych przez placówkę. Z tymi wynikami zbieżne są doniesienia Alicja Sadownik (2012, s. 125), która wskazuje, że dokumentacja szkolna uczniów, którzy trafili do szkoły specjalnej na etapie gimnazjum lub szkoły zawodowej, poświadcza „burzliwość” okresu pobytu w tych szkołach lub też „nieprzystosowalność” uczniów do różnego rodzaju norm szkolnych $(61,2 \%$ uczniów otrzymało co najmniej jedną pisemną naganę dyrektora szkoły; $69,2 \%$ uczniów nie uzyskało promocji do następnej klasy, 35,1\% było relegowanych ze szkoły; $15 \%$ miało nadzór kuratora). Autorka wskazuje, że wypowiedzi uczniów pozwalają przypuszczać, iż niektórzy uczniowie wypracowuja, wzmacniane przez rodzinę, strategie zachowania się na teście diagnostycznym w poradni psychologiczno-pedagogicznej, by znaleźć się w szkole specjalnej (Sadownik, 2012, s. 112).

Według rodziców i nauczycieli - jak wskazuje Grzyb (2013) - do zmiany placówki kształcenia uczniów z niepełnosprawnością (w związku z wydaniem nowego orzeczenia) dochodzi najczęściej na etapie gimnazjalnym - ze szkół gimnazjalnych (integracyjnych) do placówek specjalnych przeniesiono 63,4\% uczniów. Dyrektorzy badanych placówek integracyjnych zwracali uwagę na wydanie nowego orzeczenia jako decyzję wiążąca, co pozwala na wyjaśnienie, że przeniesienie ucznia z niepełnosprawnością ze szkoły integracyjnej do specjalnej zależy od sytuacji indywidualnej i odbywa się zgodnie z prawem i statutem szkoły. Przywołana autorka (Grzyb, 2013, s. 278) wskazuje, że przeniesienie ucznia z niepełnosprawnością z placówki integracyjnej do specjalnej koresponduje z oddziaływaniem czynników rodzinnych - wykształcenie rodziców uczniów rekwalifikowanych jest głównie na niskim poziomie, a znaczna część badanych ukończyła zasadniczą szkołę zawodową lub podstawową. Odwołanie do innych badań potwierdza, że status rodziny ma związek z uczęszczaniem dziecka do określonego typu szkoły. W szkołach integracyjnych uczą się często uczniowie z rodzin o wyższym statusie społecznym i ekonomicznym, wykazujący troskę o przebieg kariery szkolnej swoich dzieci (por. Parys, Olszewski, 2003; Szumski, Firkowska-Mankiewicz, 2010). Uczniowie szkół specjalnych 
wywodzą się najczęściej z rodzin niewydolnych w zakresie materialno-bytowego funkcjonowania i psychospołecznych uwarunkowań wypełniania funkcji opiekuńczo-wychowawczej (niski status ekonomiczny i społeczno-kulturowy) (por. Żółkowska, 1994; Kozubska, 2000; Janiszewska-Nieścioruk, 2010). Zróżnicowanie zapleczy rodzinnych wiązać więc należy z różnym udziałem rodziny w kształtowaniu ścieżki edukacyjnej swojego dziecka (wyższe kompetencje rodziców dziecka uczęszczającego do szkoły integracyjnej umożliwiają bardziej aktywny udział w wyborze szkoły, która w ich ocenie jest korzystniejsza dla dalszych losów dziecka). Inna możliwa interpretacja odwoływać się może do różnych potrzeb rodzin w zakresie kompensowania niewydolności opiekuńczej i przewidywania możliwości, jakie w tym zakresie niosą środowiska szkolne. Niższy status ekonomiczny rodzin dzieci uczęszczających do szkół specjalnych przy jednoczesnych ich dysfunkcjach powoduje, że funkcje: edukacyjna, rewalidacyjna i opiekuńczo-wychowawcza tych szkół są zintensyfikowane, a wymiar opieki szkolnej stanowi ważne źródło zadowolenia ze szkoły specjalnej dla samych uczniów i jako takie postrzegane jest także przez ich rodziców (por. Sadowska, 2006a; 2006c; Janiszewska-Nieścioruk, 2010, 2015). Warto podkreślić, że codzienne doświadczenie wskazuje, iż ostateczna decyzja o opuszczeniu klasy integracyjnej/ogólnodostępnej przez dziecko i umieszczenia go w szkole specjalnej przez znakomitą większość rodziców bywa w perspektywie czasu oceniane pozytywnie, a nawet bardzo pozytywnie (Krzemińska, 2012, s. 62).

Cennego materiału wyrażającego oceny kolejnych pozycji społecznych człowieka z niepełnosprawnością związanych z życiem w szkole dostarczają badania narracyjne/biograficzne osób z niepełnosprawnością intelektualną (Gabryś, 2005; Materny, 2005; 2012; Sadownik, 2011), które stanowią swoistą kontynuację podejmowanych w polu polskiej pedagogiki i socjologii edukacji badań nad losem szkolnym uczniów czy badań nad kulturami szkolnymi.

Katarzyna Materny (2012), analizując narracje 22 uczniów specjalnej szkoły zawodowej, odsłania - jak sama podkreśla - swoisty obraz miejsca, swoistą mapę mentalną związaną $\mathrm{z}$ doświadczeniami szkolnymi młodzieży $\mathrm{w}$ trzech wymiarach czasowych: przeszłości, teraźniejszości, przyszłości. Przeszłość pojawia się jako kontrapunkt wobec aktualnych doświadczeń edukacyjnych młodzieży. Oto jeden z przykładów wypowiedzi uczennicy specjalnej szkoły zawodowej uczącej się wcześniej w szkole ogólnodostępnej:

Konkursy różne są tutaj w tej szkole. Miałam okazję wygrać tutaj jeden konkurs, zajęłam pierwsze miejsce z przedsiębiorczości. Pani prowadzi też zajęcia - kółko teatralne. Też fajne. Nigdy nie myślałam, że mogłabym wystapić, a tu występowa- 
łam. Sama się zgłosiłam. W gimnazjum to nie miałam żadnych szans właśnie, z nikim się nie przyjaźniłam, a tu miałam okazję. W jasełkach brałam udział. W pokazie mody też brałam udział. Ja w ogóle chciałam tak zobaczyć swoje umiejętności, co mi się spodoba, czy się nadaję i miałam okazję właśnie w tej szkole. Mogłam wystapić w takim czymś i bardzo mi się to spodobało. Bo wcześniej nie miałam okazji, żeby mi tak dali. Tu w tej szkole jestem bardziej tak otwarta, a w tych innych tak bardziej mało się angażowałam, mało udziału brałam, a tutaj bardziej tak otwarcie. Tam byli zupełnie inni te uczniowie i nauczyciele też inni. Oni nie byli tacy bardzo źli, ale oni brali takich bardziej mocniejszych uczniów. A ci uczniowie bardziej tak między sobą, oni nas tam wyśmiewali. Źle tam było. Tu ja właśnie tak odżyłam. Tutaj więcej mogę porozmawiać z nauczycielami, uczniami i lepiej tu mi. Tam mało rozmawiałam, w klasie tam mało się zgłaszałam. A tutaj inaczej i lepsze oceny (Materny, 2012, s 116-117).

Szkoła specjalna w wypowiedzi uczennicy jawi się jako miejsce, w którym odbudowuje ona swoje poczucie kompetencji, dobrych relacji z innymi. Zauważymy, że zaniedbania zaspokojenia specjalnych potrzeb uczniów i konieczność odbudowywania poczucia własnej kompetencji i pozytywnego obrazu samego siebie podkreślają nauczyciele szkół specjalnych, do których przychodzą uczniowie z klas integracyjnych i ogólnodostępnych (por. Krzemińska, 2012, s. 62-63). Warto przypomnieć, że rozwinięte w wieku szkolnym poczucie kompetencji jest źródłem specyficznej siły, która czyni dziecko spragnionym odgrywania określonych ról, dając mu szansę na zdobycie uznania nie tylko w najbliższym otoczeniu. Wrażliwość na dziecięce potrzeby, docenianie wysiłku, zaangażowania, chwalenie za najmniejsze chociaż osiagnięcia tworzy szansę na rozwinięcie się poczucia kompetencji.

Uczniowie podnoszą wagę emocjonalnych i społecznych aspektów uczenia się. Narracje badanych wprost odnoszą się do negatywnych doświadczeń w szkołach ogólnodostępnych, które powiązać można z pracą nauczycieli:

We wcześniejszej szkole (...) nauczyciele czasami bili dziennikami po głowie, co było takie już niesprawiedliwe. Z uczniami dobrze się układało, ale z nauczycielami już gorzej było. Nigdy nie pomagali, nawet nie chcieli. Znielubiłem tej szkoły [!]. Przestałem chodzić. Dałem se takiego luzu i przestałem chodzić do szkoły (Materny, 2012, s. 120).

Podobny obraz doświadczeń wyłania się z wywiadów z uczniami gimnazjum specjalnego, jakie przeprowadziła Katarzyna Gabryś (2005). Uczniowie 
(wszyscy badani mieli większe lub mniejsze doświadczenia w szkole ogólnodostępnej) szkołę ogólnodostępną wspominają najczęściej jako przykrą, miejsce nieustannych niepowodzeń. Tylko w nielicznych wypowiedziach pojawiała się nutka żalu, że nie można było kontynuować edukacji w normalnej szkole.

Przejścia do szkoły specjalnej to niezwykle kojący/wyzwalający moment. Wyraźnie ilustrują to także badania Sadownik (2011), która przeprowadziła 67 wywiadów narracyjnych z uczniami szkoły zawodowej specjalnej. Znaczenia przypisywane przez uczniów nauce w szkole masowej badaczka uogólniła do następujących kategorii: „niepowodzenie szkolne, doświadczenia bycia wyśmiewanym, doświadczenie różnicy wieku (i wzrostu), dezorientacja w strukturze obowiązków ucznia, złe oceny, cierpienie, doświadczenie mocy poprzez stosowanie przemocy fizycznej i psychologicznej wobec nauczycieli, opinia bycia jedną ze »złych i groźnych sióstr«, przynależność do środowiska stosującego przemoc, stosowanie przemocy wobec innych w obronie honoru młodszej siostry" (Sadownik, 2011, s. 113). Autorka wskazuje, że nie wszystkie z tych kategorii dotyczą każdego ucznia. Wspólny wszystkim uczniom jest brak sukcesu szkolnego w szkole masowej, objawiający się złymi ocenami, co prowadzi ostatecznie do szkoły specjalnej (Sadownik, 2011s. 116). Przejście do szkoły specjalnej opatrzone jest przez badanych uczniów bardzo pozytywnymi określeniami. Opisują oni społeczną przestrzeń szkoły specjalnej jako sprzyjającą zrozumieniu ich stylu i tempa uczenia się. Opowiadają o ciekawych dla siebie zajęciach, zaangażowaniu w istniejące w szkole kółka i konkursy. Są też badani, którzy traktują przejście do szkoły specjalnej jako odzyskanie bliskości siostrzanej wspólnoty i solidarności w środowisku szkolnym. Mimo że przejście do szkoły specjalnej interpretowane jest przez większość uczniów (grupę zdiagnozowanych na poziomie gimnazjalnym lub zawodowym) w kategoriach działania niesłusznego i/lub niesprawiedliwego, to uczniowskie konceptualizacje codzienności w szkole specjalnej odsyłają do kategorii spokoju, zrozumienia, „fajności” i przyjemności. Znaczenia przypisywane przez uczniów nauce w szkole specjalnej badaczka uogólniła do następujących kategorii: „uwolnienie od opresyjnych rówieśników, przyjemność uczenia się w grupie o podobnych potrzebach, uczenie się i zabawa z przyjemnością, aktywność w kółku teatralnym, udział w konkursach szkolnych, własna inicjatywa pomocy w szkole, »lubienie« szkoły, doświadczenie silnej siostrzanej wspólnoty, przemoc wobec innych uczennic w obronie honoru młodszej siostry" (Sadownik, 2011s. 116).

Ważnym elementem znaczeń przypisywanych przez uczniów szkole specjalnej - jak wykazują wcześniejsze badania - jest uwolnienie od opresyjnych rówieśników. Badania narracyjne prowadzone przez Urszulę Bartnikowską 
i Agnieszkę Żytę (2007) potwierdzają doświadczenie bycia wyśmiewanym, bycia „kozłem ofiarnym”, obiektem agresji ze strony pełnosprawnych rówieśników w formach niesegregacyjnych, w tym w szkołach integracyjnych. Zauważymy, że interpretacje niekorzystnej sytuacji uczniów z niepełnosprawnością w szkołach ogólnodostępnych i integracyjnych można odnieść zarówno do niedostatków realizacji praktyki pedagogicznej, jak i rozpatrywania tej sytuacji jako rezultat procesu, który wiąże się z pojęciami dystansu społecznego, niewystarczalności społecznej, mniejszości (udział kontekstu społeczno-kulturowego). Możliwa jest także optyka interpretacyjna nawiązująca do tzw. atrakcyjności rówieśniczej (por. Sadowska, 2006b). Przywołamy, że pozytywną korelację z atrakcyjnością ma wysoka inteligencja, przyjemny wygląd fizyczny, psychiczna i fizyczna dojrzałość. Dzieci posiadające znaczne tendencje do agresji, wycofywania się, niepokoju lub kreatywności nie są łatwo akceptowane. Dzieci bywają najczęściej wybierane przez rówieśników należących do tej samej klasy społecznej (Janowski, 1980, s. 101). Nie dziwi więc gorsza sytuacja społeczna uczniów z niepełnosprawnością intelektualną w grupach heterogenicznych, co potwierdzają liczne badania na przestrzeni ponad 20 lat (por. Maciarz, 1987; Dyduch, 1999; Bąbka, 2003; Ćwirynkało, 2003; Buchnat, 2012).

Znaczenie szkoły specjalnej w perspektywie doświadczeń uczniów można dopełnić kolejnymi badaniami. Badania jakości życia w szkole prowadzone przez Sławomirę Sadowską (2006) wskazują, że uczniowie z niepełnosprawnością intelektualną ze szkół specjalnych wyrażają istotnie wyższą satysfakcję ze szkoły w wymiarze kształceniowym, rekreacyjno-opiekuńczym, relacji interpersonalnych z nauczycielami oraz koleżankami i kolegami, w porównaniu do uczniów z niepełnosprawnością intelektualną ze szkół integracyjnych. Badani przez Hannę Żuraw (2013) niepełnosprawni absolwenci zawodowych szkół specjalnych (mający doświadczenie nauki w szkole masowej) wyrażają wyższe oceny pobytu w szkole specjalnej niż ogólnodostępnej. Szkoła specjalna postrzegana była przez badanych jako miejsce pobudzenia do pracy, życzliwości, ale i wsparcia materialnego. Autorka podkreśla, że nie zaskakuje więc sympatia do szkoły i utrzymywanie kontaktów z nauczycielami już po zakończeniu nauki (Żuraw, 2013, s. 135-137).

W obliczu przywołanych badań nietrudno stwierdzić, że bezsporne są wartości działań szkół specjalnych w odbudowywaniu strat wynoszonych z błędnych praktyk edukacyjnych szkół ogólnodostępnych/integracyjnych, w których wcześniej uczyli się uczniowie z niepełnosprawnością. Te błędne działania powiązać można z przywoływaną w praktyce edukacyjnej kategorią postrzegania dziecka niepełnosprawnego jako nieporadnego, społecznie niedopasowanego, 
a w wieku dorosłym jako nieprzydatnego zawodowo i nieproduktywnego. Dla nauczycieli szkoły ogólnodostępnej i integracyjnej słowem kluczowym w opisie tych dzieci są „ograniczenia” i „niemożność” (najczęściej wyraża się to przez zaprzeczenie czasownika: „nie funkcjonuje”, „nie poradzi sobie”, „nie może...”). W języku nauczycieli szkoły specjalnej słowem kluczowym jest natomiast rzeczownik ,trudności” (por. Sadowska, 2005).

Dopełniając analizy, odwołamy się w zakończeniu do wyników badań Elżbieta Maria Minczakiewicz (2003), która z pozycji dorastającej młodzieży z niepełnosprawnością z województw małopolskiego i śląskiego rozpoznawała ponad 10 lat temu preferencje systemów kształcenia (integracyjny czy segregacyjny). Uzyskane wyniki badań jednoznacznie wykazały, iż młodzież z niepełnosprawnością intelektualną oraz młodzież z wadami sensorycznymi, zwłaszcza z wieloraką niepełnosprawnością fizyczną, sensoryczną i intelektualną (z zaburzeniami sprzężonymi), wyraźnie preferuje segregacyjny system kształcenia. Młodzież z niepełnosprawnością motoryczno-lokomocyjną oraz przewlekłą chorobą zdecydowanie preferuje integracyjny system kształcenia. W obliczu przywołanych wcześniej badań z ostatnich kilku lat sytuacja - zdaje się - nie ma podstaw do zmian.

\section{Uwagi końcowe}

Współczesne oblicze realizacji idei integracji w edukacji - jak wykazałyśmy - wskazuje na dość częste zjawisko „wydaleń” czy „powrotów” z integracji oraz wage szkoły specjalnej w budowaniu/odbudowywaniu poczucia kompetencji uczniów niepełnosprawnych, poczucia własnej wartości, dobrych relacji z nauczycielami, koleżankami i kolegami. Ogląd różnorodnych badań pozwala nakreślić wyzwania, które stają przed osobami odpowiedzialnymi za proces organizacji kształcenia. Po raz kolejny wypada nam przywołać stwierdzenie, że działania osób włączających się na rzecz integracji osób niepełnosprawnych, podporządkowane ,ideologii dystrybucji szczęścia”, podpadają pod określenie postępowania ortodoksyjnego (por. Kowalik, 2001). Należy uważnie analizować korzyści i zagrożenia, jakie dają różne formy kształcenia. Z pewnością bowiem nie dla wszystkich grup osób niepełnosprawnych oferta form edukacji integracyjnej jest odpowiednia.

Ostatnia refleksja, którą chcemy podjąć w odniesieniu do przedstawionych wyników, odnosi się do uczniowskiej szkoły marzeń. W świetle narracji uczniów specjalnej szkoły, którzy uczyli się wcześniej w innych formach kształcenia konkluzje w tym zakresie są następujące: 
Taką szkołę bym zrobił, aby uczniowie mogli dobrze się czuć w szkole.

Szkoła powinna pomagać słabszym, pomóc w nauce, by zdobyć zawód i iść do pracy.

Szkoła powinna być bez przemocy, bez awantury, to jest pierwsza rzecz. Kultura do nauczycieli, do kolegów, ogólnie do ludzi.

Szkoła powinna dawać wiedzę tak, byśmy wychodzili dumni z tego, co potrafimy (K. Materny 2012, s. 117).

Warto, by osoby zaangażowane w proces zmian, umiały te uczniowskie myśli wykorzystać.

\section{Bibliografia}

Bartnikowska U., Żyta A. (2007), Integracja szkolna we wspomnieniach dorostych z niepetnosprawnościa - koncepcja a rzeczywistość, w: T. Żółkowska (red.), Pedagogika specjalna-koncepcje i rzeczywistość, t. 2: Konteksty pedagogiki specjalnej, Uniwersytet Szczeciński, Szczecin.

Bąbka J. (2003), Psychospołeczne aspekty efektywności edukacji w systemie integracyjnym, w: Z. Kazanowski, D. Osik-Chudowolska (red.), Integracja osób niepetnosprawnych w edukacji i interakcjach społecznych, Wyd. UMCS, Lublin.

Bieniada-Krakiewicz T. (1987), Postawy rodziców dzieci i młodzieży niepetnosprawnej wobec integracyjnego systemu kształcenia $i$ wychowania, w: Integracja społeczna ludzi niepetnosprawnych - zadania pedagoga, Studia Pedagogiczne, t. 51, Zakład Narodowy im Ossolińskich, Wrocław.

Buchnat M. (2012), Sytuacja dzieci z lekkq niepetnosprawnościq intelektualnq $w$ klasach integracyjnych, w: A. Krause, J. Belzyt, S. Sadowska (red.), Dyskursy pedagogiki specjalnej, nr 10. Szkoła dla osób z niepetnosprawnościq. Wzory - Codzienność - Wyzwania, Wydawnictwo Uniwersytetu Gdańskiego, Gdańsk.

Chrzanowska I. (2009), Zaniedbane obszary edukacji - pomiędzy pedagogika a pedagogika specjalna. Wybrane zagadnienia, OW „Impuls”, Kraków.

Ćwirynkało K. (2003), Pozycja socjometryczna uczniów niepełnosprawnych a postawa nauczycieli wobec integracji, w: Z. Kazanowski, D. Osik-Chudowolska (red.), Integracja osób niepetnosprawnych w edukacji i interakcjach społecznych, Wyd. UMCS, Lublin.

Dyduch E. (1999), Izolacja społeczna uczniów z obniżonq sprawnościq intelektualnq w szkole publicznej, w: J. Pańczyk, W. Dykcik (red.), Pedagogika specjalna wobec zagrożeń i wyzwań XXI wieku. Materiały z obrad XVI sekcji III Zjazdu Pedagogicznego w Poznaniu (21-23 wrzesień 1998), Wyd. UAM, Poznań. 
Gabryś K. (2005), Kategorie personalistyczne w myśleniu o osobach niepetnosprawnych intelektualnie, w: A. Klinik, J. Rottermund, Z. Gajdzica (red.), Edukacja-socjalizacja - autonomia w życiu osoby niepetnosprawnej, Oficyna Wydawnicza „Impuls”, Kraków.

Grzelak P., Kubicki P., Orłowska M. (2014), Realizacja badania ścieżek edukacyjnych niepetnosprawnych dzieci, uczniów i absolwentów - raport końcowy, Wyd. Instytut Badań Edukacyjnych, Warszawa.

Grzyb B. (2013), Uwarunkowania zwiqzane z przenoszeniem uczniów niepetnosprawnych ze szkót integracyjnych do specjalnych, OW „Impuls”, Kraków.

GUS (Główny Urząd Statystyczny), Oświata i wychowanie w roku szkolnym 2013/2014, GUS, Warszawa 2014, http://www.stat.gov.p (dostęp: 12.01.2015).

Janiszewska-Nieścioruk Z. (2010), Problematyczna dostęność systemu edukacji dla osób z niepełnosprawnościq, „Niepełnosprawność: półrocznik naukowy”, $\mathrm{nr}$ 3, s. 41-51.

Janiszewska-Nieścioruk Z., Herberger J., Grzegorzewska I. i in. (2015), Człowiek wobec wyzwań i zagrożeń współczesności. Rozwój-rodzina-edukacja, Oficyna Wydawnicza UZ, Zielona Góra.

Janowski A. (1980), Psychologia społeczna a zagadnienia wychowania, Zakład Narodowy im. Ossolińskich, Wrocław.

Konwencja ONZ o prawach osób niepełnosprawnych, https://www.rpo.gov.pl/pl/konwencja-o-prawach-osob-niepelnosprawnych_(dostęp: 20.02.2014).

Kossewska J. (2000), Uwarunkowania postaw. Nauczyciele i inne grupy zawodowe wobec integracji szkolnej dzieci niepetnosprawnych, Wyd. Naukowe Akademii Pedagogicznej, Kraków.

Kowalik S. (2001), Pomiędzy dyskryminacja a integracja osób niepetnosprawnych, w: B. Kaja (red.), Wspomaganie rozwoju. Psychostymulacja i psychokorekcja, t. 3. Wyd. Akademii Bydgoskiej, Bydgoszcz.

Kozubska A. (2000), Opieka $i$ wychowanie w rodzinie dziecka upośledzonego umystowo w stopniu lekkim, Wyd. Uczelniane AB, Bydgoszcz.

Krzemińska D. (2012), O edukacji (nie)integracyjnej kilka refleksji, w: A. Krause, J. Belzyt, S. Sadowska (red.), Dyskursy pedagogiki specjalnej, nr 10. Szkoła dla osób z niepetnosprawnościa. Wzory - Codzienność - Wyzwania, Wydawnictwo Uniwersytetu Gdańskiego, Gdańsk.

Maciarz A. (1987), Integracja społeczna dzieci niepełnosprawnych, WSiP, Warszawa.

Materny K. (2005), „, Moje miejsce w świecie”-doświadczenia edukacyjne i społeczne młodzieży z niepetnosprawnościq intelektualnq, w: Cz. Kosakowski, A. Krause (red.), Nor- 
malizacja środowisk życia osób niepetnosprawnych. Dyskursy pedagogiki specjalnej, t. 4. Wyd. UWM, Olsztyn.

Materny K. (2012), Biografia miejsca - obraz szkoły specjalnej w narracjach uczniów, w: A. Krause, J. Belzyt, S. Sadowska (red.), Dyskursy pedagogiki specjalnej, nr 10. Szkoła dla osób z niepetnosprawnościq. Wzory - Codzienność - Wyzwania, Wydawnictwo Uniwersytetu Gdańskiego, Gdańsk.

Minczakiewicz E. M. (2003), Młodzież niepetnosprawna i jej rodzice wobec integracji edukacyjnej, w: Z. Kazanowski, D. Osik-Chudowolska (red.), Integracja osób niepetnosprawnych w edukacji i interakcjach społecznych, Wyd. UMCS, Lublin.

Parys K., Olszewski S. (2003), Dla kogo integracja?, w: E. Górniewicz, A. Krause (red.), Konteksty teoretyczne. Dyskursy pedagogiki specjalnej, Wyd. UWM, Olsztyn.

Rozporządzenie Ministra Edukacji Narodowej z dnia 24 lipca 2015 r. w sprawie warunków organizowania kształcenia, wychowania i opieki dla dzieci i młodzieży niepełnosprawnych, niedostosowanych społecznie i zagrożonych niedostosowaniem społecznym (Dz.U. 2015 r., poz. 1113).

Sadownik A. (2011), Na rozstajnych drogach. Studium etnopedagogiczne kontrastowych karier szkolnych młodzieży, Wyd. Naukowe Dolnośląskiej Szkoły Wyższej, Wrocław.

Sadowska S. (2005), Ku edukacji zorientowanej na zmianę społecznego obrazu osób niepetnosprawnych, Wyd. Edukacyjne „AKAPIT”, Torun.

Sadowska S. (2006), Jakość życia uczniów z niepetnosprawnościq intelektualnq $w$ stopniu lekkim, Oficyna Wydawnicza „Impuls”, Kraków.

Sadowska S. (2006a), Szkolne stosunki interpersonalne $w$ ocenach zadowolenia uczniów z niepetnosprawnościq intelektualnq w stopniu lekkim, „Szkoła Specjalna”, nr 4.

Sadowska S., (2006b), Ścieżka edukacyjna ucznia z niepełnosprawnością intelektualną w stopniu lekkim - aspekty trajektorii społecznej, „Szkoła Specjalna”, nr 5.

System Informacji Oświatowej (SIO): Uczniowie ze specjalnymi potrzebami edukacyjnymi w roku szkolnym 2014/2015 wg SIO stan na 30.09.2014 r. v 6, http://www.cie.men.gov. pl/index.php/dane-statystyczne/139.html (dostęp: 12.01.2015).

Szumski G. współpraca A. Firkowska-Mankiewicz (2010), Wokół edukacji właczajacej. Efekty kształcenia uczniów z niepetnosprawnościq intelektualnq w stopniu lekkim w klasach specjalnych, integracyjnych i ogólnodostęnnych, Wyd. APS, Warszawa.

Żółkowska T. (1994), Rodzina a funkcjonowanie w klasie szkolnej ucznia upośledzonego umystowo w stopniu lekkim, Wyd. US, Szczecin.

Żuraw H. (2013), Taka zwykła codzienność. Jakość życia niepetnosprawnych intelektualnie absolwentów zawodowych szkół specjalnych, Wyd. Akademickie Żak, Warszawa. 